\title{
The Impact of the Characters' Traumatic Memories on Their Family Patterns in The Joy Luck Club
}

\author{
Jiaoliu Wei \\ Chongqing Normal University, China
}

\begin{abstract}
In recent years, the study of The Joy Luck Club cannot get rid of the words "cultural conflict between the East and the West", "post-colonial feminism", "Chinese identity", "mother-daughter relationship". And Tan's The Joy Luck Club on the surface seems to write about the mode of getting along with mothers and daughters and their difficult life under the conflicts of the two cultural backgrounds between China and the United States. But making a deep analysis, the family formed by them has a unique family model, and in addition to Chinese and Western cultural conflicts and other factors that affect these four families, there is also the traumatic memory of the mothers and daughters. This paper attempts to analyze the traumas of four couples of mothers and daughters in the novel, explore the sources of these traumas. Furthermore, it will explore the impact of these traumas on the relationship between mothers and daughters, and then find out what kind of family model will be formed by the traumatized mothers and daughters.
\end{abstract}

Index Terms-The Joy Luck Club, traumatic memory, family pattern

\section{INTRODUCTION}

In the 1950s and 1960s, the rise and development of the black people's rights movement in the United States evoked some minorities' understanding of their ethnic characteristics. The group with the strongest reaction is the writer community. Compared with African-American, Hispanic writers and writers of other ethnicities, Chinese-American writers face not only racial discrimination of Americans, but also the trauma of war, poverty, disaster, famine, displacement and intangible cultural shackles from their homeland. Therefore, while criticizing American mainstream culture and opposing racial discrimination, Chinese American writers also introspect the national culture and history.

Amy Tan's works strive to make the voice of marginalized races and marginal cultures, and explore the identity of self. She is especially concerned about the sufferings and experience of traditional Chinese women and families. In her novel, "All Chinese women are victims of suffering .... The past events experienced by the four mothers in the novel represent the old China and the backward Chinese culture, and without exception mark brutality, backwardness, and ignorance" (Zhao Wenshu, 2009, p.135). And The Joy Luck Club mainly reflects the differences between two generations and two cultures by describing the story of mothers and daughters. It is in such conflicts that the mothers and daughters in the story understand that they are not purely Chinese and American, but Chinese-Americans who are compatible with Chinese and American culture (Ma Cuixia \& Zhang Li, 2014).

Family is the core carrier of traditional Chinese culture. A famous scholar points out that the important position of a family and its extended family in the society of old China ... is unmatched by any other culture (Xu Xingyan, 2004). This is why the core position of a family is always emphasized in Chinese culture. However, in The Joy Luck Club, we can clearly find that traditional Chinese families are not paradise on earth, but closer to "most Chinese families are unhappy". Unhappiness mainly comes from disasters and changes in life. These disasters and changes have brought some bad memories to every family in the novel, which become the traumatic memories that this paper will study. This paper attempts to analyze the traumas of the mothers and daughters in the novel and explore the sources of these traumas. Furthermore, it will explore the impact of these traumas on the relationship between mothers and daughters, and then find out what kind of family model will be formed by the traumatized mothers and daughters.

To analyze the impact of traumatic memories on family patterns in The Joy Luck Club, this paper mainly adopts the methods of literature research, so as to comprehensively and correctly understand their influences on the family patterns.

\section{LITERATURE REVIEW}

The success of The Joy Luck Club not only made Amy Tan become famous in the literary world, but also attracted more and more scholars at home and abroad to study the novel. Most western scholars focus on analyzing the characteristics of the gender and ethnic identity of the female image in the novel; domestically, attention is mainly paid to the issues of cultural conflicts, mother-daughter relationships, as well as the construction and narrative strategies of Chinese women in the novel. This paper summarizes several main characteristics of the current researches of The Joy 
Luck Club by scholars at home and abroad.

\section{A. Researches Abroad}

In the United States, critics have mixed reviews of The Joy Luck Club. As a Chinese-American, Amy Tan is a mixture of Chinese and Western cultures. She does not have a deep understanding of Chinese culture, but the connotation of Chinese culture runs through The Joy Luck Club from beginning to end. Tan's description about the culture of the old China in the novel provoked much controversy in foreign literary world.

\section{Perspective of Orientalism}

Due to historical reasons, there is a lack of cross-cultural communication between America and China, thus Chinese in the eyes of Americans is mysterious, ignorant and backward. The subjective description of China's traditional culture in this novel is exactly in line with the imagination of westerners, thus some critics such as Frank Chin believe that the novel is full of Orientalism. Other critics believe that in this collision of Chinese and Western cultures, Tan's subjective description of Chinese culture justifies the differences and conflicts between Chinese and Western cultures. However, some scholars believe that Tan's description of Chinese culture is a misinterpretation, and her misinterpretation is to cater to the curiosity of western readers. Zhao Jianxiu pointed out in the anthology "The Great Seal" that "the Chinese and American-Chinese depicted in Amy Tan's novels are the products of white racist imagination, neither facts nor Chinese culture, nor Chinese or American-Chinese literature" (Xu Yingguo, 2008, p.135).

\section{Perspective of Multiculturalism}

The United States is a country dominated by culture of white people and has a variety of other cultures. Because of the development of American civil rights movement, some Western people proposed multicultural ideas. Barieva Klene Railevna (2017) thinks that multiculturalism advocates the coexistence of different cultures and objects any kind of cultural discrimination (p.301). The scholars such as Harold Bloom believe that in America the formation of multiculturalism is mainly to overthrow old cultural thinking and eliminate cultural discrimination by establishing a framework of multiculturalism.

In The Joy Luck Club, the American-born daughters initially discriminated against Chinese culture, but later, in the surrounding living environment and atmosphere, they slowly merged Chinese and Western cultures and realized a multicultural atmosphere (Bloom, 2009). In 1990, Amy Ling pointed out in her book Between the Worlds: Female Writers of Chinese Ancestors that the mothers in The Joy Luck Club got rid of the damage they suffered in China. They immigrated to the United States with the hope that the next generation would lead a happy life and become the most perfect combination of Chinese and Western cultures. However, because of their gender and ethnic disadvantages, their American dream was not fully realized. They still had to find their own identity in various oppressions (Alaine, 1982).

\section{B. Researches at Home}

As one of the representative works of Amy Tan, The Joy Luck Club has been studied by many Chinese scholars. Judging from the papers searched from CNKI (China National Knowledge Infrastructure), one of the Chinese paper databases, with the keyword "The Joy Luck Club", from 2010 to 2020, the journal articles on it are still increasing, with a total number of 594 articles. This shows that scholars' research on The Joy Luck Club is still gradually deepening and exploring from more different perspectives.

\section{Perspective of Cultural Differences}

Most studies analyze how mother-daughter contradictions and solutions have risen to the conflict and integration of Chinese and Western cultures, and explore the misinterpretations and generation gaps in mother-daughter relationships, different identities and values, and the novel's attitude toward Chinese traditional culture and the identity of new culture construct. In Peng Taoying's (2005) article "Separation, Conflict and Integration of Chinese and American Cultures: An Interpretation of The Joy Luck Club", she thinks that "The Joy Luck Club recognizes the differences between the culture of China and America and does not avoid their conflicts. The most gratifying thing is that it firmly believes in the ultimate fusion of culture is possible and inevitable" (p.48). In Li Xiaojun and Li Xiaohong's paper "From The Joy Luck Club to Crazy Rich Asians: The Oriental Imagination of Contemporary Hollywood and the Development of Asian Culture", they pointed out that "in the two major regional spaces of China and the United States, they have chosen four different specific scenes link the life encounters of four mother-daughter and three-generation women to reflect the social and cultural differences between the East and the West" (2019, p.112).

\section{Perspective of Post-Colonialism}

Post-colonialism mainly studies the political, social and cultural impact of Western colonization, and attempts to decolonize and change the destiny and values of mankind (Qin Nan, 2007). From the perspective of post-colonialism, women have been struggling to find their cultural identity under the marginalization and alienation. In The Joy Luck Club, Tan stands at the height of American culture to tell Chinese stories. Because mothers and daughters are in different positions, they are "others" to each other. In this "alienation space", they lose their cultural identity.

\section{Perspective of Feminism}


Feminists attempt to change women's position in society and traditional education and social practice's prejudice against women, exposing the various oppression of women in patriarchal society. In literature, analyzing the experience of women in literary works from the perspective of feminism, we may discover that they live without rights in the patriarchal society. As a female writer, Tan's novels mainly focus on women's living conditions and status. In this novel, she describes the sufferings of women's lives to reflect the discrimination and oppression of women's images. Huang Ping (2013) used Beauvoir's "other" theory to explore how women in The Joy Luck Club became "others" in a "cultural melting pot" like the United States. He pointed out that in the so-called patriarchal society, the women who lived in China, especially those who have endured numerous pains, fought desperately in search of their own value and cultural identity (p.46).

\section{Perspective of Narratology}

The special narrative strategy is the key factor to the long-term success of this work. A lot of domestic scholars have analyzed the novel's narrative features from different angles. From the perspective of spatial narratology, Pang Li (2014) interprets the opposition, transformation and integration of literature reflected in it. The article points out that the novel's narrative breaks the time limit and juxtaposes different cultural spaces with the same theme, revealing the theme of cultural identity. The dislocation narrative strategy of time and space reflects the distortion of mothers and daughters. Daughters born in the United States could not sense the living environment of the mothers; the generation of mothers in the United States rejected the culture denominated by white Americans and later accepted it to realize the transformation of space; the final reconciliation of mothers and daughters reflected the fusion of two different cultures.

\section{Inadequacy of Previous Studies}

Foreign scholars' research perspectives mainly focus on the difference between East and West, but there are few other aspects involved. For domestic research, there are relatively many perspectives. Most of the studies on the novel are about the cultural conflict and integration between China and America. Many related research viewpoints are similar and have no unique opinions. In terms of studies of the narrative characteristics, the narrative theories used in those researches are also relatively common. Scholars who study from the perspective of feminism mainly analyze the process of women from oppression to liberation, but these analyses are similar. The author believes that the effects of traumatic memories on the family model of mothers and daughters in this novel can be analyzed in depth from related theories of traumatic memory.

\section{THEORETICAL FOUNDATION}

\section{The Definition of Traumatic Memory}

Traumatic memory refers to those psychological, emotional, and even physiological abnormalities caused by serious injury events in life. It mainly includes two elements: first, the cause of trauma must be an event with sufficient intensity, and second, it emphasizes the experience of the event in the individual's heart (Zhao Dongmei, 2009). A traumatized victim is always immersed in the traumatic memories of the past, such as the memory fragments of injury events will constantly appear in his dream or imagination. Many ordinary things in one's life may become a trigger point of his traumatic memory, and may also awaken his psychological experience of those traumatic events. In addition, the victims showed selective forgetting. At the same time, in the unconscious, past victims are also very likely to be the perpetrators of traumatic events (Jung, 1978).

\section{The Sources of Traumatic Memories AND Their Influences on FAMILy Patterns}

The Family System Psychological research represented by Murray Bowen's and Virginia Satir shows that the family is a complete and indivisible system, and any event in the family will leave a trace on everyone (Corey, 2005); "the relationship model between parents and children is the basis of the relationship between children and others" (Wu Zhihong, 2007, p.50). Experiencing too much trauma may completely change the original attitudes and feelings towards life, and leave many shadows in the collective consciousness of the whole family that cannot be rid of to cause more pain. This paper attempts to analyze the traumas of mothers and daughters in the novel, explore the sources of these traumas, and further explore the impact of these traumas on mothers and daughters' relationship, and find out what kind of family model will be formed by the traumatized mothers and daughters.

\section{A. Controlling Lindo Jong and Self-Indulgent Waverly Jong}

\section{The Sources of Lindo Jong's Traumatic Memories}

Lindo Jong's traumatic memories came from her experience from two years old to her arrival in the United States. When she was 12 years old, her hometown was destroyed by floods and her family moved south. But she stayed there unwillingly and married a man whose mother was scornful. She was scolded and closely controlled by her mother-in-law for no reason. Even though she later broke free of her tragic family life through her ingenuity, successfully escaped from her husband's family, and then transferred to the United States, there were still "scars" in her life which was difficult to heal. Freud believes that the losses of childhood, such as the departure of loved ones, the 
instability of care relationships, are particularly likely to cause children's traumatic experiences and form profound traumatic memories (Freud, 1998). Lindo clearly remembered that when she was two years old, she saw a matchmaker come to her house together with Mrs. Huang for the first time. That memory was so impressed, because from that moment on, she subconsciously realized that her role at home had changed since her mother's love for her began to lose gradually. Then, her mother sent her a message, intentionally or unintentionally, that her mother-in-law would be Mrs. Huang in the future. When she married her husband at the age of 12, her maternal love completely left her and she positioned Mrs. Huang as the new mother. However, she did not feel Mrs. Huang's love, only the endless frustration brought by Mrs. Huang's blame and control.

\section{The Sources of Waverley Jong's Traumatic Memory}

Lindo's daughter, Waverley, was very confident and fully inherited her mother's tenacity and savvy. However, Lindo Jong, who was once under the tight control of her mother-in-law, also formed a very serious desire to control under the subtle influence of her mother-in-law, and subconsciously exerted strong control over Waverly. Waverley had been good at chess since she was a child. Her mother was always proud of this award and made a big deal about it all the time. However, she hated her mother for this move. A fierce clash between the mother and daughter occurred. Jong showed extreme indifference to the growth and the two marriages of her daughter. Lindo's attitude towards Waverly made her feel that her mother no longer loved her. Finally, Lindo mentally suppressed Waverly in the form of cold violence, and foiled her resistance.

\section{The Influences of Their Traumatic Memories on Their Family Model}

The relationship between Lindo Jong and Waverley is the same as the relationship between Lindo Jong and her mother-in-law, because the person who plays the role of mother has a strong desire to control. As a daughter, Waverley said: "It was for me, a scared child, who had run away a long time ago to what I had imagined was a safer place. And hiding in this place, behind my invisible barriers, I knew what lay on the other side: Her attacks. Her secret weapons. Her uncanny ability to find my weakest spots" (Tan, 2006, p.203). In handling all affairs, Lindo's mother-in-law always attacked her, but she dared to fight against her destiny and changed her destiny with extraordinary shrewdness and courage. When it was her turn to deal with the relationship with her daughter, she unconsciously followed her mother-in-law's approach, thus Waverly felt the blame and blow from her mother in all aspects. As a result, they formed an antagonistic family model. In this family, the mother was indifferent and had a strong desire to control, the daughter was silent but silently resisted the mother's command.

Kinship is the driving force behind the child's psychological development. The three most important self-elements, attachment experience, object relationship, and self-identification, are formed under the care of family (Freud, 1998). Lindo Jong did not get a positive attachment experience when she was a child. Her love had always been suppressed, and she also did not know how to love her daughter. The long-term depression of love made her pass on her indifference and negation to her daughter. And the long-term lack of attachment experience with her mother also made Waverly live with scars of love since childhood. These traumatic memories further affected their family model, in which mother and daughter were deeply hurt in silence.

\section{B. Overly Hopeful Suyuan Woo and Unconfident Jing-Mei Woo}

\section{The Sources of Suyuan Woo's Traumatic Memories}

Suyuan Woo in the novel had twin daughters before immigrating to the United States. When the Japanese invaders hit Guilin, she was forced to flee, but exhausted on the way and finally had to leave her daughters on the roadside, hoping that the children would have a chance to be alive. However, she did not die. After being rescued, she chose to leave China and went to the United States. And later her youngest daughter Jing-mei Woo was born. "Abandoning the babies" became a "scar" on Suyuan's mind which was difficult to relieve. Thus, she turned her guilt of abandoning her children into exquisite love for her younger daughter. She poured all her love and hope on Jing-mei Woo in order to redeem her love for the twin daughters. This torture of mental guilt accompanied her for life.

\section{The Sources of Jing-Mei Woo's Traumatic Memories}

When Jing-mei Woo was young, her feelings, personality, dreams, and values were not accepted by her mother. She had to live in the way prescribed by her mother. Although Jing-mei worked very hard, her efforts were not recognized by her mother. She couldn't play the piano as much as her mother wished. The failure of the piano performance gave her mother the most fatal blow and because of this, her mother was "a quiet, blank look that said she had lost everything" (Tan, 2006, p.151) and caused her the greatest harm. "In the years that followed, I failed her so many times, each time asserting my own will, my right to fall short of expectation" (Tan, 2006, p.254). Long-term negative feedback had caused Jing-mei's poor self-identity, which influenced her ability to coordinate the psychological balance of inferiority and self-esteem, as well as her ability to create and develop.

\section{The Influences of Their Traumatic Memories on Their Family Model}

In the traditional Chinese family model, parents always consider their children above everything else, and will pour all their love on their children. However, if the parents' love is too heavy, the child is often overwhelmed, thus this 
heavy love will become harmful to the child when the limit is reached. The recipient's defense mechanism will unconsciously resist this love, manifesting in an inferiority and rebellious character. This can be seen from the relationship of Suyuan Woo and Jing-mei Woo. The mother's weighty love made the whole family have a strong sense of heaviness, and also made this family form a kind of family model that only allowed obedience and no resistance. Consequently, this kind of family model made Jing-mei Woo lose herself.

\section{Compliant An-Mei Hsu and Obedient Rose Hsu Jordan}

\section{The Sources of An-Mei Hsu's Traumatic Memories}

An-mei Hsu's traumatic memories mainly came from her mother. An-mei Hsu's mother, a young widow, was forced to marry a businessman as a concubine after being raped, and this identity was a shameless and difficult matter for Chinese families at the time. As a result, her mother was cast aside by her mother's family and they refused her to take An-mei. In a quarrel, the adults accidentally knocked over the soup pot, scalded An-mei, and left her with a permanent scar, and more seriously, also caused her an unhealable mental "trauma". The whole family, especially An-mei's grandmother, considered her mother as a shame. The grandmother told An-mei: the "obedient" women are good women, while the "disobedient" women, like her mother, are bad ones. The denial and trample of her mother's image left An-mei with great trauma. She treated her psychological trauma through forgetting. According to Freud (1920), oblivion is a primitive defense mechanism. "In two years' time, my scar became pale and shiny and I had no memory of my mother. That is the way it is with a wound. The wound begins to close in on itself, to protect what is hurting so much. And once it is closed, you no longer see what is underneath, what started the pain" (Tan, 2006, p.40).

After the death of her grandmother, An-mei followed her mother to her new home. But soon her mother committed suicide in despair because she couldn't stand the humiliation her husband gave her. Since then, An-mei was completely separated from her mother. However, even though her mother left her by suicide, the mother's lifestyle of being submissive and patient with her husband still left a mark on An-mei. Although America did not have the feudal system of old China, women did not need to rely on the husband's breath to survive but without self, they still cannot become themselves in front of their husbands (Aliss, 1993). Therefore, on one hand, An-mei hoped that Rose was obedient, but on the other hand, she imagined that Rose would not be dominated by others when she became an adult.

\section{The Sources of Rose Hsu's Traumatic Memories}

An-mei's daughter, Rose Hsu Jordan, received the message from her mother since childhood that: Obedience is good, and having your own ideas is not good. This toxic doctrine made Rose lose herself. At the same time, the grandmother and mother's patriarchal ideas and the weak status of women were all highlighted in Rose's personality, which made her completely lose herself. Patience swallowed and indecision became the collective unconsciousness among their generations of women. The traditional Chinese concept of "Three Concerns and Four Virtues" advocated by the mother and grandmother generation also narrowed Rose's mind. After getting married, Rose put herself in the position of obedience, desperately covering up her true thoughts, and only trying to please her husband, causing her husband to have her no opinion, dissatisfaction with her dependence, but this kind of behaviors caused her husband to have dissatisfaction because he thought she had no opinion and was too dependent, which triggered a marriage crisis. This is exactly the same as the way Auntie Four (An-mei's mother) treats her husband.

\section{The Influences of Their Traumatic Memories on Their Family Model}

There are many unhealthy elements in Chinese traditional family culture (Gu Yue, 2011). The interests and reputation of a family often override the values and happiness of an individual. For Chinese, "the individual has no independent development direction and personality, but only as a stage of genealogy ... People get marry not just for themselves, but for the family" (Sa Mengwu, 2005, p.79). An-mei and Rose have flaws in attachment experiences, objective relationships, and self-identity. They restrained loving each other and never dare to love too warmly. This kind of love makes their families manifest forbearance everywhere. In this kind of family model, no matter mother or daughter, obediently obey others. The root cause of this family model is the patriarchal thought that penetrates into their deep consciousness.

\section{Loveless Ying-Ying St. Clair and Self-Abundant Lena St. Clair}

\section{The Sources of Ying-Ying Clair's Traumatic Memories}

At the beginning of the novel, Jing-mei's evaluation of Ying-ying St. Clair was: "Aunt Ying has always been the weird auntie, someone lost in her own world" (Tan, 2006, p.24). Ying-ying herself also thought that she was a walking dead, liking a ghost. She attributed it to her experience of the Mid-Autumn Festival when she was young. At that time, Yingying was separated from the family members, and accidentally fell into the water. After she was rescued, she was lost. Later, she saw a "Moon Lady" in the shadow play and became the goddess of happiness in her heart. She couldn't wait to run to the background and asked the "Moon Lady" to help her realize her wish---"to be found." However, she was astonished by the result. The "Moon Lady" she saw was actually a dirty man. She had been lost in her own world ever since, and her behavior also became weird and abnormal.

For Yingying, the series of events that occurred on that day had a strong spiritual impact and had sufficient strength, 
so she had a strong inner experience, which caused her great trauma. The same event may bring different levels of internal experience for different persons. And individuals, especially children, have low affordability. Yingying was mainly looked after by her nanny. Her mother did not look after her often, but the feudal and conservative nanny did not provide meaningful counseling. In Ying-ying's heart, although her mother was under the same roof with her, she didn't really feel the mother's love. Therefore, Yingying's trauma became deeper and deeper and healed.

\section{The Sources of Lena Clair's Traumatic Memories}

The painful traumatic experience not only affected the mother's generation, it continued to spread between generations like a ghost, so that the daughter's generation was still suffering. For Lena St. Clair, her mother had always lived in her world, while the motherhood was absent. Yingying did not give Lena the motherhood she deserved, but used her own consciousness to internalize her daughter's self-awareness, restrain her daughter's behavior, and educate her in a formal way. However, she did not clear her daughter's mind. From her childhood, Lena only felt the fear, insecurity and extreme superstition brought by her mother, and she was always excluded when she longed to enter the mother's world. She inherited her mother's "trauma". On the surface, she was independent, self-reliant and very ambitious, but her mother's receptive personality and fatalistic emotions were intertwined, which deeply affected her and made her subconsciously and negatively accept the inequality and dissatisfaction in marriage. She had made equal contributions to the company in her career with her husband, but only paid one-seventh of her husband's salary, and never got the promotion she deserves. She was traumatized by the rules of this evenly distributed and seemingly equal game of marriage. And her family life was full of obedience.

\section{The Influences of Their Traumatic Memories on Their Family Model}

In the novel, both generations of mother and daughter were somewhat lacking in self, and this was largely a product of the family. Although the traditional family culture emphasizes the education of children, it ignores the children's spiritual construction in words and deeds, which has caused strong neglect and destruction to children (Gu Yue, 2011). Since Lena was born, she had subtly absorbed the results of her mother's words and examples. Therefore, her lifestyle was accompanied by the humility and tenderness unique to traditional Chinese women. And these caused her to have many conflicts with her husband.

\section{CONCLUSION}

It can be found from all the analysis that the traumatic memories of the two generations not only brought great pain and suffering to mothers but also daughters. The family system psychological research represented by Murray Bowen's and Virginia Satir tells us that if an unhealthy family model and mental state are not recovered in the previous generation, they will often be repeated in the latter generation. If we observe the four families in The Joy Luck Club carefully, we will find amazing repeatability. Here we see how motherhood's childhood family model is reproduced in daughters again. And this repetitiveness also makes their family model not be changed easily between generations, and is still passed down from generation to generation. Therefore, in the novel, the mother is affected by the traumatic memory of the previous generation, the daughter is affected by the traumatic memory of the mother, and the family models of the three generations show striking similarities.

\section{REFERENCES}

[1] Amy, T. (2006). The Joy Luck Club. Shang Hai: Penguin Books.

[2] Barieva, K, R. (2017). Multiculturalism in Education: Barriers of Communicative Creativity in the Case of Nonresident and Foreign Students in Group Training tasks Solving. Russia: Elabuga Institute Kazan Federal University.

[3] Cathy, C. (1996). Unclaimed Experience: Trauma, Narrative and History. Baltimore and Mary and Johns Hoskins Up.

[4] Corey, G. (2005). Theory and Practice of Counseling and Psychotherapy. Belmont, California: Brooks/Cole.

[5] C G. Jung. (1933). Modern Man in Search of a Soul. Translated by W. S. Dell and Cary F. Baynes.

[6] Freud, S. (1920). A General Introduction to Psychoanalysis. Horace Liveright, New York. http://dx.doi.org/10.1037/10667-000 (assessed 18/02/2020).

[7] Freud, S. (1998). The Unconscious and Arts. Beijing: China Renmin University Press.

[8] Harold, B.( 2009). Amy Tan's The Joy Luck Club. Chelsea House Pub.

[9] Huang Ping. (2013). Escape from the Other--- the Feminist Awakening in The Joy Luck Club. Wuhan University of Technology.

[10] Jia Ping. (2009). Cultural Differences between East and West from the Theme of Maternal Love in the Joy Luck Club. Masterpieces Review, 10, 92-94.

[11] Kim, A. (1982). Asian American Literature: An Introduction in the Writing and Their Social Context. Philadelphia Temple Up.

[12] Lin Pin. (2015). Analysis of Literature Research and Literature Research Methods. Shanghai: Young Pioneer Research, 1, $22-23$.

[13] Li Xiaoyun, Li Xiaohong. (2019). From The Joy Luck Club to Crazy Rich Asians: Contemporary Hollywood's Eastern Imagination and Asian Culture Development. Contemporary Cinema, 1, 110-114.

[14] Liu Yun. (2003). The Eternal Mother/ Daughter Love: Short Story Cycle and Mother/Daughter Relationship in The Joy Luck Club. Foreign Language and Literature, 5, 51-55.

[15] Laurie, A, P. (1993). Contemporary Family Communication: Messages and Meanings. New York: St. Martin's Press.

[16] Michelle, B. (2012). The Nature of Trauma in American Novels. Illinois: Northwestern University Press. 
[17] Ma Chuixia, Zhang Li. (2014). A Study on the Theme Changes of Chinese American Female Writers' Literature Works. Overseas English, 23, 223-225.

[18] Pang Li. (2014). Space, culture and Theme: A Spatial Narrative Exploration of The Joy Luck Club. Journal of Liaoning Educational Administration Institute, 3,108-110.

[19] Peng Taoying. 2005. Cultural Gap, Conflict and Coexistence: A Study of The Joy Luck Club [A]. Journal of Hohai University (Philosophy and Social Sciences), 1, 47-49.

[20] Qin Nan. (2007). On the Translation Strategies in Lin Yutang's C-E Translation---A Study from the Perspective of Postcolonialism. Nanjing University of Aeronautics and Astronautics.

[21] Sa Mengwu. (2005). Outlaws of the Marsh and China's Society. Beijing: Beijing Publishing House.

[22] Wu Zhihong. (2007). Why Home Hurts --- Reveal the Truth about Family Life. Beijing: World Book Publishing House.

[23] Xu Xingyan. (2004). Comparison between Chinese and Western Cultures. Beijing: World Book Publishing House.

[24] Yang Xiao. (2013). A Successful Reinterpretation of Traumatic Novels with New Literary Trauma Theory. Foreign Literature Studies, 1, 169-172.

[25] Zhao Donemei. (2009). Mental Trauma Understood by Freud and Jung. Journal of Nanjing Normal University (Social Science Edition), 6, 93-97.

Jiaoliu Wei was born in Chongqing, China in 1996. She received her bachelor of art degree from Chongqing Normal University, Chongqing, China in 2020.

She is currently a post-graduate student in the School of Foreign Languages and Literature, Chongqing Normal University, Chongqing, China. Her research interests include applied linguistics, English and American literature and translation theory and practice. 